\title{
A Rapid and Efficient Method for the Isolation of Mitochondrial DNA From Wheat Crop
}

\author{
Muhammad Ejaz ${ }^{1}$, Zhang Gaisheng ${ }^{1}$, Zhu Qidi ${ }^{1} \&$ Zhang Xinbo ${ }^{1}$ \\ ${ }^{1}$ College of Agronomy, Northwest A\&F University, Yangling, Shaanxi, China \\ Correspondence: Muhammad Ejaz, College of Agronomy, Northwest Agricultural and Forestry University, \\ Yangling, Shaanxi 712100, China. Tel: 86-137-7254-6690. E-mail: ejaz_quetta@yahoo.com
}

Received: March 2, 2013 Accepted: April 5, 2013 Online Published: May 15, 2013

doi:10.5539/jas.v5n6p32 URL: http://dx.doi.org/10.5539/jas.v5n6p32

\begin{abstract}
The mitochondrial DNA was isolated from wheat (Triticum aestivum) crop in combination of different centrifugation and density gradient ultracentrifugation, DNaseI enzyme treatment, sucrose sedimentation; lysis with SDS and potassium proteinase. Pure mitochondrial DNA was successfully obtained by phenol/chloroform/isoamyl alcohol extraction to remove protein, and digested with RNase phenol/chloroform extraction method. To detect mitochondrial DNA purity, specific primers were designed for nuclear ( $\beta$-actin) and mitochondrial (COXII) gene. Isolated mitochondrial DNA is pure, suitable for PCR and genetic analysis.
\end{abstract}

Keywords: wheat, yellow etiolated shoots, mitochondrial DNA isolation

\section{Introduction}

Mitochondria play an important role in the development and reproduction of plant, encoding necessary proteins involved in the system of energy production. They occupy a specific evolutionary pattern relative to nuclear counterparts (Lynch et al., 2006). Numerous metabolic pathways at cellular site of mitochondria are essential for higher eukaryotic life (Logan, 2006; Reichert, 2004). Principal pathways are the tricarboxylic acid cycle, respiratory electron transfer and ATP synthesis (Logan, 2006; Barrientos, 2003). Isolation of mtDNA is particularly difficult and protocols developed for one species often do not work for other species (Hanson et al., 1986). This phenomenon is due to intact plant tissue may be the abundance of phenolic compounds which are known to exist in differentiated plant tissues. Moore and Proudlove (1983) reported that phenolic compounds bind strongly to mitochondrial membranes and are thought to be destructive to the integrity of the mitochondria. The protocol presented in this paper evolved from a protocol described by Li et al. (2007) for wheat crop and may serve as a guide for the development of other mtDNA isolation protocols.

\section{Material and Method}

\subsection{Plant Material}

In this investigation wheat (Triticum aestivum) line 1376 was used. The seed was soaked in water for 6 hours, Wheat yellow etiolated seedlings were grown in dark over a period of 7 to 10 days at $30^{\circ} \mathrm{C}$ in growth chamber and they meet their growth needs by on nutrients only supply sterile water. The plants were strictly protected from light. All the cultural practices were done in dark, prevent them to become green and get a high quality mtDNA which is free from chloroplast, genomic DNA and other impurities.

\subsection{Mitochondria Isolation}

We isolated mitochondria, ground $20 \mathrm{~g}$ of fresh etiolated yellow leaf, in high ionic-grinding buffer $[50 \mathrm{mmol} / \mathrm{L}$ Tris- $\mathrm{HCl} \mathrm{pH}=8,0.3 \mathrm{~mol} / \mathrm{L}$ mannitol, $0.2 \mathrm{~mol} / \mathrm{L}$ sucrose , $25 \mathrm{mmol} / \mathrm{L}$ EDTA $\mathrm{pH}=8,0.1 \%$ bovine serum albumin (BSA), $0.6 \%$ Polyvinylpyrrolidone (PVP) and $0.1 \% \beta$-mercaptoethanol], BSA, PVP and $\beta$-mercaptoethanol added before use; $10 \mathrm{ml} / \mathrm{g}$ tissue; filtered it with 6 layer of Mira cloth. Centrifuged at $3500 \mathrm{rpm}$ for 10 minutes on $4^{\circ} \mathrm{C}$ discarded the chloroplast and nuclear DNA pellets. The supernatant was centrifuged at $10000 \mathrm{rpm}$ for 20 minutes on $4^{\circ} \mathrm{C}$. Re-suspended the pellets in buffer solution $(50 \mathrm{mmol} / \mathrm{L}$ Tris- $\mathrm{HCl} \mathrm{pH}=8,0.3 \mathrm{~mol} / \mathrm{L}$ mannitol, $0.2 \mathrm{~mol} / \mathrm{L}$ sucrose, $0.1 \% \mathrm{BSA}$ and $0.6 \% \mathrm{PVP}$ ) gently used soft paint brush, centrifuged at $3500 \mathrm{rpm}$ on $4^{\circ} \mathrm{C}$ for 10 minutes discarded the nuclei pellets. Supernatant was centrifuged at $10000 \mathrm{rpm}$ for 20 minutes at $4^{\circ} \mathrm{C}$. To eliminate nuclear DNA, the mitochondrial pellet was re-suspended in $10 \mathrm{ml}$ of cold buffer $(0.2 \mathrm{~mol} / \mathrm{L}$ sucrose, $50 \mathrm{mmol} / \mathrm{L}$ Tris- $\mathrm{HCl} \mathrm{pH=8)}$ added $100 \mu \mathrm{l} \mathrm{MgCl} 2(1 \mathrm{~mol} / \mathrm{L}), 8 \mu \mathrm{l} \mathrm{DNaseI}(50 \mathrm{ng} / \mathrm{ml})$ (Segma) enzyme and Incubated on ice for 
90 minutes. The reaction was stopped by added EDTA- $\mathrm{Na}_{2}$ to a final concentration was $0.2 \mathrm{~mol} / \mathrm{L}$. Washed the

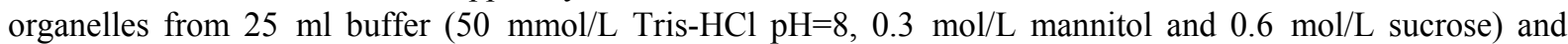
Collected the organelle pellets of mitochondria by centrifuged at $10000 \mathrm{rpm}$ for 20 minute, at $4{ }^{\circ} \mathrm{C}$.

\subsection{Mitochondrial DNA Isolation}

The mitochondrial pellets was re-suspended in lysis buffer $(25 \mathrm{mmol} / \mathrm{L}$ Tris- $\mathrm{HCl} \mathrm{pH}=8,25 \mathrm{mmol} / \mathrm{L}$ EDTA , 5\% SDS, $0.1 \mathrm{~mol} / \mathrm{L} \mathrm{NaCl}$ and $0.1 \% \beta$-mercaptoethanol) and added $100 \mu \mathrm{g} / \mathrm{ml}$ potassium proteinase, incubated at $50^{\circ} \mathrm{C}$ and then $37^{\circ} \mathrm{C}$ on each temperature for 60 minutes. The mtDNA was cleaned with 2 mol/L $\mathrm{NH}_{4}$-acetate, phenol/chloroform/isoamyl alcohol $(25: 24: 1)$, pH 6.7 and centrifuged at $18000 \mathrm{~g}$ for 5 minutes on $4^{\circ} \mathrm{C}$. (Repeat the step). mtDNA was washed with Chloroform/isoamyl alcohol (24:1) and Centrifuge at $18000 \mathrm{~g}$ for 5 minute at $4^{\circ} \mathrm{C}$. RNA was removed from the samples with $10 \mu \mathrm{g} / \mu 1$ DNase-free RNase enzyme (Sigma) and incubated at $37^{\circ} \mathrm{C}$ for 60 minutes. Purified the mtDNA by added ice cold anhydrous ethanol, $1 / 10^{\text {th }}$ of $3 \mathrm{~mol} / \mathrm{L} \mathrm{CH}_{3} \mathrm{COONa}$ and incubated at $-70^{\circ} \mathrm{C}$ for 60 minutes. Pelleted mtDNA by centrifuged at $18000 \mathrm{~g}$ for 15 minutes on $4^{\circ} \mathrm{C}$. mtDNA was washed with ethanol 70\% (2 times) and 96\% (1 time). Dry at room temperature, re-dissolved in TE-buffer (10mmol Tris and $1 \mathrm{mmol}$ EDTA $(\mathrm{pH} 8.0)$ and store at $-20^{\circ} \mathrm{C}$.

\subsection{Quality Test}

mtDNA Quality were measured at absorbance ratio A260nm, A280nm and calculated optical density (OD) value, used UV spectrophotometer for purity analysis.

\subsection{Polymerase Chain Reaction and Electrophoresis}

PCR reactions were performed in $20 \mu$ volumes with $50 \mathrm{ng}$ mtDNA, $6 \mu$ lddH $\mathrm{H}_{2} \mathrm{O}, 1 \mu \mathrm{l}$ (forward and reverse) primer of each specific-gene ( $\beta$-actin and COXII gene) and $10 \mu \mathrm{l}$ of master mix. Performed in an Eppendorf Mastercycler using the following program: $94^{\circ} \mathrm{C}$ for $5 \mathrm{~min}$ followed by 5 cycles at $94^{\circ} \mathrm{C}$ for $1 \mathrm{~min}, 60^{\circ} \mathrm{C}$ for $30 \mathrm{sec}$ and $70^{\circ} \mathrm{C}$ for $1 \mathrm{~min}, 35$ cycles of $50 \mathrm{sec}$ at $94^{\circ} \mathrm{C}, 1 \mathrm{~min}$ at $60^{\circ} \mathrm{C}$, and $50 \mathrm{sec}$ at $72^{\circ} \mathrm{C}$ and final extension at $72^{\circ} \mathrm{C}$ for $6 \mathrm{~min}$. PCR products were separated on $1 \%(\mathrm{w} / \mathrm{v})$ agarose gels electrophorese and ethidium bromide staining.

\section{Result and Discussion}

The mtDNA was extracted from yellow etiolated shoots (20 g) of wheat crop (Scotti et al., 2001), used the method of Li et al. (2007) with some amendments. Removed the genomic, Plastid DNA by DNaseI enzyme treatment. Proteinase k was used to remove the protein. RNA was removed by RNase enzyme treatment. The mtDNA, OD values !ratio of A260/A280 was in between 1.81 to 1.99 , at A260/A230 1.90 to 2.0 and the concentration of mtDNA/ $\mu 1$ was in between 559 to 590 (Table 1) which indicates the good quality mtDNA (Figure 1).

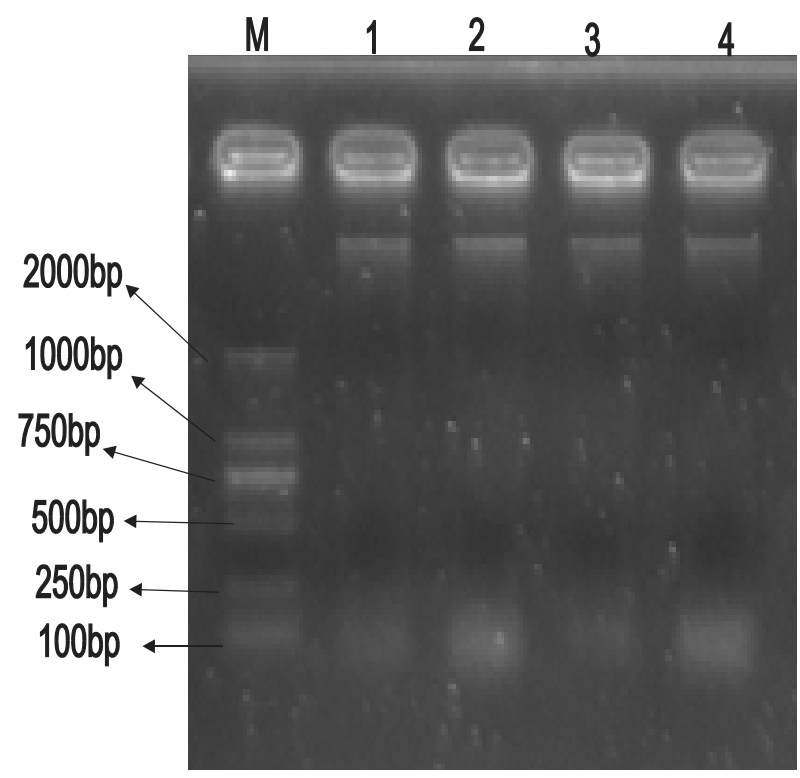

Figure 1. Results of mtDNA

M: Marker, Wheat line 1376 (1-4). 
Purified mitochondrial pellets from genomic DNA organelles applied DNase I enzyme treatment. This DNase I enzyme concentration can be adjusted as needed for the different plant species until the nuclear DNA amplification is undetectable (Christine et al., 2004). For the mtDNA purity assessment, we analyzed samples through amplification of nuclear $\beta$ subunit ( $\beta$-actin) actin genes and the mitochondrial $\mathrm{C}$ oxidase subunit (COXII) gene. The products were separated on a $1 \%(\mathrm{w} / \mathrm{v})$ agarose gel electrophoresis. Mitochondrial COXII gene 400bp was amplified and $\beta$-actin gene was not amplified, so the mtDNA was not contaminated by nuclear DNA, plastid DNA, RNA, protein, and was successfully used for PCR, cloning and southern blot analyses (Figure 2).

Table 1. Spectrophotometer values of mtDNA

\begin{tabular}{ccccc}
\hline Sr.No. & & A260/A280 & A260/A230 & $\mathrm{ng} / \mu 1$ \\
\hline 1. & 1.99 & 2.00 & 559 \\
2. & 1.81 & 1.90 & 590 \\
& 1.92 & 1.99 & 585 \\
3. & 1.89 & 2.00 & 569 \\
\hline
\end{tabular}

Values of Wheat line $1376(1-4)$.

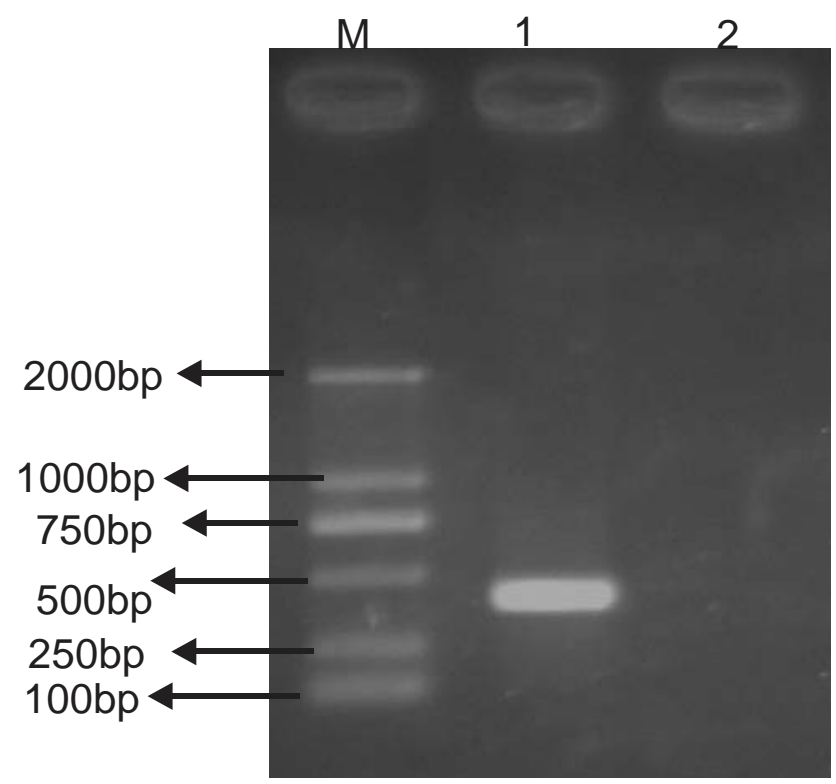

Figure 2. M. Marker 1. COXII gene 2. $\beta$-actin gene

M: Marker, Wheat line 1376 (1-2).

\section{References}

Barrientos, A. (2003). Yeast models of human mitochondrial diseases. IUBMB Life, 55, 83-95. http://dx.doi.org/10.1080/1521654031000098122

Christine, G., Stoeva, P., Cheely, A., \& Dimaculangan, D. (2004). RAPD analysis of mtDNA from tomato flowers free of nuclear DNA artifacts. Winthrop University, Rock Hill, SC, USA and 2 AgroBioInstitute, Sofia, Bulgaria. BioTechniques, 36, 772-776.

Hanson, M. R., Boeshore, M. L., McClean, P. E., O'Connell, M. A., \& Nivision, H. T. (1986). The isolation of mitochondria and mitochondrlal DNA. Methods in Enzymology, 118, 437-453. http://dx.doi.org/10.1016/0076-6879(86)18091-8

Li, W. Q., Zhang, G. S., Wang, K., Niu, N., \& Pan, D. L. (2007). An efficient method for isolation of mitochondrial DNA in wheat, Yichuan (Hereditas), 29(6), 771-775. 
Logan, D. C. (2006). The mitochondrial compartment. J. Exp. Bot., 57, 1225-1243. http://dx.doi.org/10.1093/jxb/erj151 PMid:16556626

Lynch, M., Koskella, B., \& Schaack, S. (2006). Mutation pressure and the evolution of organelle genomic architecture. Science, 311, 1727-1730. http://dx.doi.org/10.1126/science.1118884 PMid:16556832

Moore, A. L., \& Proudlove, M. O. (1983). Mitochondria and sub-mitochondrial particles. In J. L. Hall, \& A. L. Moore (Eds.), Isolation of Membrane and Organelles From Plant Cells (pp. 153-183). London: Academic Press.

Reichert, A. S., \& Neupert, W. (2004). Mitochondriomics or what makes us breathe. Trends Genet, 20, 555-562. http://dx.doi.org/10.1016/j.tig.2004.08.012

Scotti, N., Cardi, T., \& Marechal-Drouard, L. (2001). Mitochondrial DNA and RNA isolation from small amounts of potato tissue. Plant Mol. Biol. Reptr, 19, 67a-67h. http://dx.doi.org/10.1007/BF02824080 